\title{
Entrevista com Rubim Santos Leão de Aquino
}

Interview with Rubim Santos Leão de Aquino
Esta entrevista foi feita no Rio de Faneiro,
em 17 de abril de 2008,
pelos editores de Estudos Históricos
Américo Freire Angela de Castro Gomes

Formado no começo da década de 1960 pela Faculdade Nacional de Filosofia da Universidade do Brasil, hoje UFRJ, Rubim Santos Leão de Aquino pode ser considerado o decano dos professores de história de ensino médio do Rio de Janeiro. Como muitos de sua geração, iniciou a carreira no magistério em cursinhos pré-vestibulares, passando depois a acumular essa atividade com aulas em alguns dos principais colégios da rede privada da cidade. Em fins dos anos 1970, esteve à frente da equipe que publicou História das sociedades, livro didático de grande repercussão junto ao professorado e aos alunos de ensino médio, que hoje se encontra na $49^{\mathrm{a}}$ edição.

\footnotetext{
Américo Freire é doutor em história social e professor associado do CPDOC/FGV, Rio de Janeiro (americo.freire@fgv.br). Angela de Castro Gomes é doutora em ciência política, professora titular da Universidade Federal Fluminense (UFF), professora titular e coordenadora do Programa de Pós-Graduação em História, Política e Bens Culturais do CPDOC/FGV, Rio de Janeiro (acastro@fgv.br).
} 
Vamos começar por alguns dados pessoais: quando e onde você nasceu, como era sua família, qual foi sua formação escolar?

- Nasci no Rio de Janeiro em 2 de março de 1929, quer dizer, estou com 79 anos. Meu pai, Rubens Monteiro Leão de Aquino, chegou a marechal do Exército; minha mãe, Maria Antonieta Santos de Aquino, como se diz hoje, era "do lar". Como sou filho de militar, meus estudos foram todos picados. O primário, fiz praticamente em casa. A família contratava professores e eu fazia as provas em casa. Fiz o exame de admissão num colégio aqui do Rio, depois mudei para Curitiba e lá fiz o primeiro ano ginasial e uma parte do segundo. Em seguida meu pai foi transferido para Campo Grande, no atual Mato Grosso do Sul, e lá terminei o ginásio em uma escola estadual, o Ginásio Campo-Grandense. Já o curso científico, fiz em um colégio de padres, o Colégio Dom Bosco. ${ }^{1}$ Quando eu estudava no Campo-Grandense, um professor que me marcou muito foi Hostácio Ruiz. Era um advogado que dava aula de História.

Na escola, você se envolvia em atividades como grêmio estudantil, jornal de alunos etc.? Atividades com, digamos, algum espírito político?

- Posso dizer que minha primeira experiência desse tipo foi em Curitiba. Foi quando o Brasil declarou guerra à Alemanha. Eu devia ter por volta de 13 anos e participei de uma passeata que foi organizada para quebrar os clubes alemães e italianos. Estava todo animado, quando alguém me puxou pelo colarinho. Era meu pai, que me tirou do ato político, da "bagunça"... Mais tarde, em Campo Grande, já no fim do Estado Novo, me envolvi com o Partido Trabalhista Brasileiro. Eu gostava do PTB... Na volta para o Rio, acabei me filiando a esse partido. E o meu velho ficava maluco!

Como foi essa volta para o Rio?

- Meu pai queria que eu continuasse os estudos, mas tratei logo de arrumar um emprego. Eu tinha uma tia que trabalhava no Gabinete Civil da Presidência da República e me arranjou uma colocação como arquivista no Ministério da Fazenda. Foi lá que conheci Sara Mota Lima, filha do importante dirigente do Partido Comunista Brasileiro Pedro Mota Lima. ${ }^{2}$ Acabei me casando com ela, que foi minha primeira mulher e marcou muito a minha vida.

\section{E como você se relacionou com o sogro comunista?}

- Muito bem. Seu Pedro também exerceu uma influência muito grande na minha formação. Ele nunca me pediu para votar no pessoal do PCB. Na época, eu ainda acreditava naquela história de "comunista come criança", "ouro de Moscou", esses chavões todos que se dizia e ainda se diz por aí. Mas ele passou a me mostrar que as coisas não eram bem assim, e comecei a ver os comunistas com um olhar diferente. 
Em que ano você se casou?

- Eu me casei em 1951. E fiz com a Sara o seguinte trato: "Tudo bem, você continua com as suas idéias, comunista, mas cessa as suas atividades partidárias." Porque ela atuava muito com o pessoal do PCB, fazendo propaganda de rua, esquetes com Mário Lago no rádio. Além disso, combinei com ela que os nossos filhos seriam batizados, e ela concordou. $\mathrm{Na}$ época eu me considerava católico. Hoje não, hoje acho que sou comunista cristão. Nós tivemos sete filhos, dos quais dois faleceram: Paulo e Roberto. Estivemos casados 21 anos. No começo, ela vivia dizendo para mim: "Por que você não volta a estudar?" Eu tinha terminado o científico em 1947.

\section{Sara cursou alguma faculdade?}

- Não, a família dela não tinha recursos para isso. Seu Pedro era "funcionário" do PCB. Foi um dos fundadores do Partido e dirigiu um dos seus jornais, Imprensa Popular. ${ }^{3}$ Às vezes as coisas ficavam feias e ele tinha que se esconder; quando as coisas aliviavam, ele aparecia. Teve uma vida difícil. Nenhum dos filhos chegou a estudar em faculdade.

Talvez por isso ela quisesse tanto que você estudasse.

-É, talvez. Ela dizia: "Você já pensou que, quando os nossos filhos crescerem, vão perguntar o que o pai era? 'Funcionário público.' Você não fica chateado?" Ficou me martelando para estudar. Até que um dia, creio que no final de 1957, ela chegou em casa e disse: "Olha, aqui está o programa de vestibular da Faculdade Nacional de Filosofia. Tem o pré-vestibular que funciona à noite. Está tudo na sua mão. Se você quiser, vai estudar.” Aí eu fui.

Abre parêntese: você disse que se filiou ao PTB ao voltar para o Rio. Em 1954, como você viu a crise política que culminou no suicídio de Vargas?

- Quando houve toda aquela campanha liderada pelo Lacerda contra Getúlio, eu já tinha feito concurso e trabalhava na Alfândega. No dia 24 de agosto, por volta de oito e meia da manhã, veio a notícia de que o Getúlio tinha se suicidado. De pronto eu cheguei para o meu chefe e disse: "Não dá para continuar trabalhando. Vou para a rua". Fui para a rua do Acre, onde havia uma grande multidão, e saímos para empastelar $O$ Globo. Fui caminhando no meio daquela gente toda, de terno e gravata - eu só andava de terno e gravata naquela época-, e chegamos ao largo da Carioca. Ali era a sede d'O Globo, onde hoje é o Edifício Avenida Central. Mas não deu para invadir e quebrar tudo, porque havia grades de ferro enormes, o que nos levou a virar os carros de distribuição d'O Globo. Pusemos fogo neles e dali marchamos para empastelar a Tribuna da Imprensa, que 
era o jornal do Carlos Lacerda. Só que o jornal estava guarnecido com o pessoal da Aeronáutica, que era ligado ao Lacerda. Pessoal de baioneta calada, metralhadora etc. Então resolvi ir embora para casa. No dia seguinte, acompanhei o cortejo fúnebre do Getúlio do Palácio do Catete até o aeroporto Santos Dumont. Estive sempre metido com política, me mantive ligado ao PTB até 1964. Quando veio o AI-2, que acabou com os partidos políticos, entrei para o Movimento Democrático Brasileiro, o MDB, que era o partido de oposição.

Voltando aos seus estudos: em 1957, então, você foi se preparar para fazer o Curso de História da Faculdade Nacional de Filosofia. Na época, os cursinhos pré-vestibulares eram muito importantes. Como foi sua experiência como vestibulando? Quem dava aula? Eram os próprios professores da faculdade, ou eram os alunos?

- Eram os alunos da FNFi, como a gente chamava. Dos que nos deram aula, eu destacaria a Nely Moulin, que foi da última turma de História e Geografia. Hoje em dia, ao que parece, foi para a área de pedagogia. Na época, nós tínhamos um grupo de estudos formado por cinco pessoas, três casados e dois solteiros, e todo domingo nos reuníamos na praça em frente ao aeroporto Santos Dumont. Ficávamos lá estudando, mais ou menos de oito e meia da manhã até o meio-dia e meia. Depois, cada um ia para a sua casa.

Além de você, quem compunha esse grupo da praça?

- Um deles, hoje, trabalha na Universidade do Maranhão. É curioso, porque chegou a ser seminarista, mas hoje está metido com cultura e religião africana. É o Sérgio Ferretti. Outro acabou sendo até diretor do Instituto Benjamim Constant. É o João Delduque Pinto Filho. E houve um que chegou a ser professor do IFCS: Ondemar Ferreira Dias. Dava aula de História da América, mas o negócio dele era arqueologia. Tinha também o Joel Sanches, que largou história e foi para pedagogia. Não sei se ele ainda está na Universidade Gama Filho.

E como foi o exame vestibular?

- Aconteceu uma coisa curiosíssima. Naquele tempo havia prova escrita e depois oral. Você tinha que ter no mínimo 4 por matéria para ir adiante. Mas mesmo que você tivesse $4 \mathrm{em}$ todas as matérias não passava, porque precisava de média global 5 para entrar. Fui fazer a prova oral de História com o Hugo Weiss, um dos melhores professores que tive, e que, infelizmente, já faleceu. Ele perguntou: "Você estudou?" Eu: "Estudei mais ou menos. Acho que sim." Ele: "Então, vou lhe fazer um desafio. Vou fazer uma única pergunta, e se você responder, lhe dou 10. Se não, dou 0.” Pensei: se eu não responder, ele não vai ter co- 
ragem de me dar 0 . Vai me perguntar alguma outra coisa e descontar. Mas se eu responder e acertar, aí eu ganho 10. Resolvi correr o risco e nunca mais me esqueci dessa pergunta. Ele pediu para eu explicar uma diferença entre o humanismo italiano e o humanismo alemão. Olha o que era o vestibular! Respondi e ganhei 10. Passei em segundo lugar no vestibular! Mas o sujeito que passou em primeiro não cursou a faculdade, não sei por quê - acho que queria ir para o Itamaraty -, e acabei sendo o primeiro lugar.

Em 1958, então, você entrou para a FNFi. Gostaríamos que nos falasse sobre seu curso: os professores, os colegas, as leituras. Primeiro, os professores.

- Eu tive uma gama de professores de grande renome: Maria Yedda Linhares, que era catedrática de História Moderna e Contemporânea, e que peguei no terceiro e no quarto anos; Hugo Weiss, que era seu assistente. Na área de História da América, cujo catedrático era o Sílvio Júlio de Albuquerque Lima, que nunca nos deu aula, quem ministrava os cursos era Marcelo Ipanema, que mais tarde acabou presidente do Instituto Histórico e Geográfico Brasileiro. Também em História da América havia uma professora cuja aula era tão chata que a gente fazia rodízio para assistir. Eu sempre fui muito moleque, brincalhão. Um dia ela chegou em sala e disse assim: "Olha, vocês avisem aos seus colegas para não faltarem à próxima aula, porque eu vou dar um assunto importantíssimo, sobre $o$ qual vocês só costumam estudar a visão portuguesa. Vou mostrar a visão espanhola. É sobre o Tratado de Madri. Vou trazer uma cópia original do tratado." Quer dizer, uma cópia original. Eu disse: "Professora, traz duas, que eu faço coleção de cópias originais!” Ia por aí afora.

\section{Quem trabalhava com História do Brasil?}

- Hélio Viana, que era cunhado do Castelo Branco. O assistente do Hélio Viana era Manuel Maurício de Albuquerque, o Maneco, que se tornou muito meu amigo e me ajudou muito na carreira. $\mathrm{Na}$ área de Antiga, o catedrático era Eremildo Viana, que terminou personagem do Sérgio Porto, aproveitado pelo Elio Gaspari como Eremildo, o idiota.$^{4} \mathrm{Na}$ Didática, era Anísio Teixeira. ${ }^{5}$ Lembro-me ainda do Faria Borges, que tinha sido oficial de Marinha. Vocês sabem tão bem quanto eu que os alunos combinam fazer perguntas que não têm nada a ver com a matéria, para o professor não dar aula. Tipo: "Professor, a gente soube que o senhor é oficial de Marinha. Está na ativa ainda?" - "Não. Estou na reserva." - "E como é que era? O senhor viajava?" - "Viajava." - "E como é que era o negócio a bordo? Tinha mulher?" - "Não." - "E aí? Como é que vocês se distraíam?" - "A gente fazia festa, dançava." Quando ele viu o que disse, e viu a gente olhando um para o outro... "Era de rosto colado, mão dada?" Ficou danado da vida! 
Como esses professores davam aula? Quem era bom professor?

- Hugo Weiss era fora de série. Manuel Maurício, excepcional. Outro bom professor era o Guy de Holanda. Às vezes a aula dele era muito chata, porque ele era capaz de falar 50 minutos sobre a importância da mula na colonização espanhola. Ele dava duas matérias: Introdução ao Estudo da História e História da América. Também ficou muito meu amigo, porque o pai dele era ligado ao Seu Pedro, meu sogro. Ele ia à minha casa, morava perto.

$E$ as aulas de Anísio Teixeira? O que você achava?

- Eram chatas. Era assim: as aulas eram dadas em um anfiteatro, havia o quadro-negro - que era verde, não era negro -, abria-se uma porta e entravam as assistentes dele; uma limpava o quadro, outra arrumava a mesa e a outra fazia a chamada. Aí ele entrava. Mas as aulas não eram boas; ninguém prestava atenção: uns jogavam batalha naval, outros cochilavam...

Vocês tinham idéia de quem era Anísio Teixeira?

- Eu não tinha. Nas aulas ele nos parecia muito triunfalista.

Fazendo um balanço, você gostou do curso?

- Não sei como foi o curso de vocês... No primeiro ano a gente fica apavorado, porque os professores entram em sala, dão listas de 30, 40 livros, e a gente fica pensando que vai ter que ler aquilo tudo. Até o dia em que se descobre que existe um livro de cabeceira do professor. Mas isso só se descobre no segundo ano. $\mathrm{O}$ curso era muito pesado, muito mesmo. Por exemplo, no primeiro ano, na primeira prova de História Antiga que fiz, escrevi 16 páginas. E tirei 6. As provas duravam o dia inteiro. Começavam às oito, oito e meia da manhã e iam até o meio-dia, uma hora da tarde. Depois do almoço, recomeçavam às duas horas, $\mathrm{e}$ iam até às sete da noite. Isso para responder a quatro questões, sem consulta. Em Idade Moderna, a mesma coisa. Era o dia inteiro de prova.

Qual era o horário das aulas?

- No primeiro ano, era tudo de manhã. No segundo e no terceiro, de tarde. Mas não tinha hora certa. Por exemplo, havia dias em que você tinha aula de meio-dia às duas da tarde, e outros, de uma às três.

Como você conciliava estudo e trabalho?

- Eu saí de uma seção em que a gratificação era às vezes cinco, dez vezes mais que o meu salário, e fui para o arquivo, para poder fazer o curso. O problema foi o quarto ano. Aí eu tinha aula às sete horas da manhã no Colégio de Aplicação, na Lagoa, e ficava lá até meio-dia. Depois tinha uma aula no Centro de uma às três 
e, por exemplo, outra aula de cinco às sete da noite. Aí tive que tirar licença-prêmio. Foram seis meses de licença, mais um mês de férias, e ainda uma licença médica por um mês. Mesmo assim não deu, porque foi o ano de 1962, e já tinha greve pra chuchu. O negócio estava caminhando, era greve a toda hora. Em 1961, quando houve o movimento da legalidade, que o Brizola desencadeou, ${ }^{6}$ também foi outra luta. O quarto ano, foi uma tourada para eu conseguir completar.

Pelo que você está dizendo, predominava uma abordagem, digamos, mais tradicional da História. Fá havia alguma influência do marxismo?

- Guy de Holanda tinha umas aulas mais abertas. Manuel Maurício, o Maneco, por exemplo, ainda não era marxista. Nessa época, a gente pode dizer que ele era cristão. Mas a aula dele era muito rica. Só que, quando o Hélio Viana entrava em sala, a aula mudava. Por exemplo, aula sobre escravidão no Brasil: Hélio Viana dizia quantos escravos se calculava que tivessem entrado - segundo fulano, entraram tantos, segundo beltrano... Não se fazia qualquer menção às relações de produção. Eu me lembro que estava dando aula na Universidade Gama Filho, de História da América, quando me fizeram uma pergunta e eu fiquei bobo. A pergunta era sobre modo de produção asiático. Eu nunca tinha ouvido falar naquilo. Ninguém falava nessas coisas. Só fui aprender depois que saí da faculdade.

\section{O que você leu na faculdade?}

- Li vários livros da Coleção Civilização, da PUF (Presses Universitaires de France), da Payot, e alguma coisa da Que sais-je? Ou seja, literatura francesa. Pelo menos na cadeira de História Antiga. Nas cadeiras de Moderna e Contemporânea, os professores davam livros em francês e em inglês. Em Brasil, só se lia o Hélio Viana e nada mais. Em uma aula dele, tive a pachorra de listar os 110 nomes que ele citou enquanto ensinava invasão holandesa. Eu tinha pavor que nas provas ele fizesse perguntas sobre nomes e datas, porque sabia que eu não ia me lembrar de nada. No vestibular, quando me examinou, ele pediu para eu mencionar os nomes de dois cientistas brasileiros do século XX. Eu disse: César Lattes. Ele: "Não. Vivo não vale. Tem que ser morto."

Algum professor usava ou apresentava, em sala de aula, mapas ou documentos para trabalhar com os alunos?

- Talvez na cadeira de História Moderna e Contemporânea. Eventualmente. Dos professores, esqueci de mencionar uma que foi cassada após 1964, Marina Vasconcelos. Ela chegou a ser diretora, e o assistente dela era Darcy Ribeiro. Mas, na época, Darcy estava mais em Brasília, e quem dava aula para nós era o Carlos Moreira, que morreu outro dia. 
Quando terminou o curso, você estava razoavelmente satisfeito com a sua formação?

- Eu achava que estava. Num primeiro momento, achava que estava sabendo muita coisa. Eu, na verdade, não pretendia dar aula, porque tinha estrabismo divergente. Tanto que dizem que até hoje tenho um defeito: quando fico falando, a minha pálpebra esquerda cai, como em um mecanismo de defesa. Naquela época, meu medo era fazer uma pergunta para um aluno, e outro, em outro lugar da sala, responder. Então, eu não queria dar aula. Mas um dia, quando ia sair com minha mulher, perguntei: "Onde estão as jóias que eu te dei? Por que você não usa mais?" Ela começou a chorar e confessou que tinha colocado as jóias no prego, porque o dinheiro não dava e ela não queria me chatear, via que eu estava estudando, me esforçando. Depois disso, mudei de idéia e comecei a dar aula no preparatório para a Escola de Sociologia e Política da PUC, em 1963-64. Dei aula também na Gama Filho e em muitos cursinhos. Comecei a dar aula que nem um maluco.

E por que a opção pelos cursinhos?

- São várias as razões. Uma delas era que, por ser funcionário do Ministério da Fazenda, não poderia atuar como professor na área pública. Tanto é que recebi convites para ser professor do Pedro II e ser assistente do Marcelo Ipanema na FNFi, e não pude aceitar. Depois, com o golpe militar, para assumir qualquer cargo público você tinha que ter um atestado de ideologia. Eu não tinha. Por isso, comecei a dar aula em cursinhos e em faculdades também. Aparecia um convite, eu estava dando aula. Chegou uma época em que eu dava aula no Curso Boechat, no Curso Hélio Alonso, na Faculdade Gama Filho, na PUC e sei lá onde mais. Cheguei, uma época, a ter oito empregos! Era uma loucura. Eu começava a dar aula às sete horas da manhã e acabava às 11 horas da noite. Dava aula sobre as coisas mais diferentes. Na PUC, eu dava História do Brasil e Geral; nos cursinhos, dava aula de tudo!

\section{O que também significava estudar, preparar aula...}

- Ah, claro. Vou dar um exemplo concreto. Na Nacional de Filosofia, em História Antiga e Medieval, a gente estudava da quarta dinastia egípcia até a décima oitava. No cursinho, você tinha que dar toda a história do Egito. Então, eu tinha que preencher esse buraco.

E como era dar aula nesses cursinhos? Em geral, havia um número enorme de alunos em sala, as condições eram difíceis.

- É verdade, mas isso dependia muito do cursinho. No Miguel Couto-Bahiense, por exemplo, havia turmas com 150 alunos. Ali na Presidente Wil- 
son tinha um salão que era chamado de Maracanã. No Veiga de Almeida tinha outro salão desses, também chamado de Maracanã. As aulas eram com microfone, estrado e... mandando bala. Até, às vezes, eu ficava chateado, porque gosto de brincar com os alunos, mesmo não fazendo como outros professores que transformavam a aula em picadeiro.

Naqueles anos 60, como você lidava com os constrangimentos, com os controles políticos de toda ordem? Havia, inclusive, infiltração de policiais em sala de aula...

- Eu me lembro, por exemplo - isso deve ter sido por volta de 1970-, que estava dando uma aula na Tijuca, no tal Maracanã, quando um aluno virou e disse: “Aquino, posso tirar uma dúvida?" Eu: "Pode". Ele: "A gente está numa democracia?" Isso no governo do Médici. ${ }^{7}$ Pensei rápido: se eu digo que estamos, e o garoto tem consciência política, vai achar que eu sou um idiota; mas se eu digo que não estamos, posso ser processado etc. A sorte é que eu lia jornal todo dia. Então respondi: "Olha, não sei se você viu que na semana passada o líder do governo no Senado, senador Filinto Müller, da Arena, disse que nós não estamos numa democracia. Eu não vou contestar o senador Filinto Müller.” Já outro aluno chegou um dia para mim e me consultou: "Aquino, olha só. Fui convidado para entrar para o MR- $8 .{ }^{8}$ O que você acha?" Eu disse: "Você sabe o que é que é o MR-8? É uma organização de luta armada. Você pode entrar e podem acontecer várias coisas: você pode ser morto, pode ser preso ou pode não acontecer nada. Agora, o que você decidir, não me diga, porque eu não quero nem saber.”

As coisas eram assim. Outro exemplo. Como eu dava aula no Curso Platão, em Ipanema, uma garota chegou para mim e disse: "Aquino, me diz uma coisa. Eu sou filha de militar, meu pai morreu, e minha mãe faz reuniões lá em casa, a que sempre vão colegas do meu pai. Outro dia, um coronel virou para mim e disse: 'Olha, eu tenho uma proposta para você, que pode dar um dinheirinho: você vai nos dizer o que é que os professores estão dizendo em sala de aula, e o que os seus colegas estão comentando'." Nesse caso, eu disse a ela: “O negócio é o seguinte. Se você é a favor desse regime político aí, você vai trabalhar para ele. Se você é contra, você vai recusar ser espiã dos seus colegas e dos seus professores. Porque é disso que se trata. Mas eu não quero saber da sua decisão, não.” Não sei se ela topou ou não. Enfim, havia infiltração em todo canto.

\section{Mesmo com tudo isso, você gostava de trabalhar nos cursinhos?}

- Adorava e ainda adoro. Adoro dar aula, até hoje. Não sei viver sem dar aula. Você constrói relações com muita gente. Por exemplo, o Cássio Cunha Lima, governador da Paraíba. Eu o chamava de "cangaceiro". E o chamo até hoje. Há três anos houve uma festa, ele estava lá, e eu disse: "Ô cangaceiro!" O Ciro Garcia, que é um dos líderes do PSTU, ${ }^{9}$ e que é chamado de metralha gira- 
tória, foi meu aluno e é meu amigo. O mesmo posso dizer do Chico Alencar e de muitos outros. Para mim, esse tipo de trabalho foi uma opção de vida. Entendi que meu trabalho não era na área universitária: meu trabalho seria junto à juventude. O problema não é - numa expressão fascista - fazer a cabeça dos outros. Não se trata de fazer a cabeça de ninguém. Mas acho que o educando, o ser humano, tem uma coisa preciosa: é o pensar. Se a gente obriga o homem a pensar, a ter clareza das coisas, ele tem mais condições de fazer uma opção de vida e de ser um cidadão. Se pensar igual a mim, ótimo. Se não pensar, pelo menos, que pense algo.

Naqueles primeiros tempos nos cursinhos, nos colégios, você certamente escreveu muitas apostilas. Como se deu a passagem do uso de apostilas para o livro didático?

- Quando comecei a dar aula, eu achava os livros didáticos umas cretinices. Eu me lembro que uma das coisas que me ajudaram muito a escrever foram as aulas do Hugo Weiss. No segundo ano, ele dava a cada aluno da turma um livro didático para analisar. Eu me lembro bem daquele questionário de fixação da aprendizagem que vinha depois de cada um dos capítulos. Até hoje guardo uma das perguntas daqueles questionários: "O que fazem os cariocas no mês de verão?” O aluno podia dizer qualquer coisa: transam, vão para a farra, e você tinha que aceitar, porque era uma pergunta imbecil.

Quer dizer, você achava que os livros eram ruins.

- Ruins e chatos. Foi então que comecei a indicar o livro do Leo Huberman, História da riqueza do homem. É um livro excelente, só que não é didático. Às vezes o leitor se perde com certos dados que o autor dá só para ilustrar o capítulo: o valor do salário de um tecelão na Inglaterra em 1600 era não sei quanto; o de um tecelão na Inglaterra em 1700 etc. Não é isso que interessa, claro. Até que, em 1977, o José Luiz Werneck me indicou à editora Ao Livro Técnico para escrever uma coleção de livros para o ensino médio. Aí nasceu História das sociedades.

\section{Como você montou sua equipe de trabalho?}

- Chamei o Oscar Campos, que havia sido meu aluno, e ele indicou uma colega: Denize Franco. Além disso, como eu queria usar no livro alguns escritos do Jaques Alvarenga, que havia sido muito meu amigo e fora morto em 1973, fui à casa da mãe dele e propus que o Jaques entrasse como co-autor e ela como herdeira. Peguei o material que ele havia deixado e começamos a trabalhar. Um dia, cheguei lá na editora e me disseram que o livro estava parado e os diretores queriam uma reunião comigo. Foi uma reunião muito difícil. Um dos diretores era militar e a crítica comeu solta. Vou dar a vocês alguns exemplos. Eu não podia usar a palavra expropriação, porque era uma linguagem comunista. Eu disse: "Isso é brincadeira! Isso está nos documentos! Em vários documentos do perío- 
do colonial existe a palavra expropriação!" Outro problema foi aquela foto famosa do Mussolini pendurado pelos pés, com a Clara Petacci e os outros ministros. Eles: "Não pode. Isso é a negação da autoridade." Eu: "Mas coronel, o senhor tem coragem de dizer isso? O senhor é oficial do Exército, que mandou a FEB para guerra. Seus companheiros morreram lá na Itália, e o senhor diz isso?! Ah, eu acho que fascista tem que acabar assim mesmo!" Ou seja, a foto acabou saindo. Mas ele encrencou também com uma charge em que aparecia um cavaleiro prussiano pisando em cima de cabeças de cadáveres, de esqueletos. Disse: "Não pode. Esse livro é contra a guerra. Como é que a gente vai ensinar patriotismo para as crianças, sendo contra a guerra?” Eu então argumentava: “Coronel, o senhor tem que entender uma coisa: a sua formação é diferente da minha. $O$ senhor estudou para ser um guerreiro, para ser um combatente; eu estudei para ser um humanista, um educador. Patriotismo não tem nada a ver com guerra ou com forças armadas!" E o livro acabou saindo. E aconteceu o que eles não esperavam: começou a vender pra chuchu. Dali para a frente nunca mais me chatearam, e eu escrevo o que eu quero.

Voltando a essa sua atividade de autor de livros e também de apostilas. Como as apostilas eram feitas? Os cursinhos ganhavam com a venda, os autores recebiam? Como era, digamos assim, essa dinâmica autoral?

- Vocês sabem que é uma porcaria o que a gente ganha de direito autoral. Quando eles pagam bem, geralmente pagam no máximo 10\%; e assim mesmo, de quatro em quatro meses, ou de seis em seis. De vez em quando chamavam e diziam: "Ó, tem isso para você receber". Em suma: os cursinhos ganhavam muito dinheiro, e a gente não.

Você tem um método de trabalho para escrever material didático? Estabelece algumas regras para os que vão trabalhar com você??

- Uma das coisas que eu digo quando escrevo e coordeno, é o seguinte: primeiro, história é passado; o verbo é sempre no passado. A não ser quando há uma continuidade: o sistema capitalista foi e é. Mas não se pode dizer: a República vai ser proclamada. Não. A República foi proclamada. Outra: a frase deve ser curta. Devem-se evitar palavras que compliquem. Por exemplo. Quando fiz História das sociedades, havia uma palavra pela qual eu era apaixonado. Não me lembro qual era. Mas aí descobri em sala que os alunos não sabiam o que significava, não entendiam. A juventude hoje tem um vocabulário muito estreito por causa da televisão. Há coisa de uns quatro anos, eu estava dando um assunto em sala de aula, e de repente me deu um estalo. Perguntei: o que é que vocês querem estudar a partir de 1945? A maioria disse Igreja. Está bom. Comecei a fa- 
lar de encíclica, concílio, e perguntei: "Fulano, o que é uma encíclica?” Ninguém da turma sabia. Nas outras duas turmas, a mesma coisa. Os alunos hoje têm um vocabulário limitadíssimo. Por isso é difícil escrever, e por isso, o História das sociedades, quando a gente fez, voltava-se para o ensino médio. ${ }^{10}$ Só em alguns colégios era usado na oitava série. Mas hoje em dia, cada vez mais, ele está sendo usado em faculdades.

A que você atribui o sucesso de História das sociedades? Afinal, já são 49 edições.

- Entendo, hoje, que é um livro ao qual o garoto, de início, reage. Mas quando ele entende o espírito do livro, adora. Tenho até autografado livro de pai de aluno.

E qual é o espírito do livro?

- Ele tem que ajudar a pensar alguma coisa, sem desprezar aquilo que em História é importante: os fatos e as pessoas envolvidas nos fatos. O homem pode ser o agente da História, mas como o representante de um grupo social, de uma classe social. O livro combina tanto a parte, digamos assim, econômica, como a parte social, política e ideológica.

Conte um pouco mais sobre seu método de trabalho. Por exemplo, a pesquisa de imagem, como é feita?

- Primeiro, as charges que aparecem nos meus livros, sou eu que bolo. Todas elas. Dou a idéia e peço para alguém desenhar. Já as fotografias, ora eu aproveito imagens já existentes, ora mando alguém fotografar ou eu mesmo fotografo. Também escolho os mapas. Sobre as imagens, há uma coisa da qual não abro mão e brigo com os produtores: não gosto de ter imagens de figuras individuais, por exemplo, de Getúlio, de heróis. Uma das poucas imagens em que aparece um desses personagens é aquela foto do Jânio Quadros em que ele está com o pé para um lado e o corpo para o outro. Coloco essa foto para ridicularizar a figura. Acho que a imagem é um recurso importante para o professor discutir com seus alunos. Eu me considero um jurássico: não tenho celular, não sei escrever a máquina, não sei mexer em computador. Mas, ao mesmo tempo, quando estava muito em sala de aula, e particularmente durante a ditadura, passava filmes, mandava ver peças de teatro e fazia perguntas em cima daquilo na prova. Havia um filme que eu gostava muito de passar e que hoje, felizmente, saiu em DVD. É o Nuit et brouillard, Noite e sombra. E um filme do Alain Resnais sobre o campo de extermínio de Auschwitz. Eu passava esse filme para os alunos do Franco-Brasileiro e a reação sempre era muito forte; alguns choravam, saíam de sala. O filme é terrível, terrível, mas é excelente. 
Como é que você enfrentou, no caso dos livros que você organizou, e particularmente desse que tem já muitas edições, questões práticas como, por exemplo, tamanho dos capitulos, forma de fixação da aprendizagem...?

- Vamos começar pelo fim. Como o vestibular naquela época, fins dos anos 70, era todo na base da múltipla escolha, havia um problema: como fazer a fixação? Se você colocasse no livro uma pergunta de múltipla escolha, não matava o assunto; se pusesse quatro, cinco, ou seis questões, o livro ficaria imenso. Pensei: como é que eu vou fazer? Resolvi pegar um programa do vestibular, ver quais eram os objetivos de cada capítulo e então criar uma seção chamada Pontos a destacar. Foi inclusive por isso, e outras coisas que inventei junto com a minha equipe, que História das sociedades foi classificado como um marco na feitura de livros didáticos de História no Brasil. Depois de cada capítulo, colocamos as seguintes seções: Destaques da unidade; Para saber mais, que é indicação de uma bibliografia básica (geralmente, aqueles livrinhos da Brasiliense); ${ }^{11}$ Cinema também é História, uma seção que eu criei e que hoje todo mundo usa, que faz sugestões de filmes; e por fim, algo que não inventei, mas copiei de outros, que é a lista de sites, chamada Navegando na internet.

Atualmente, no Brasil, o Ministério da Educação compra uma grande quantidade de livros didáticos para as escolas. Eles são examinados por comissões de avaliação, compostas por professores. Como você vê o trabalho dessas comissões?

- Coloco em suspeita o trabalho dessas comissões. Eles fizeram muitas restrições a duas coleções que coordenei e das quais fui um dos co-autores. Com isso, acabaram matando essas coleções, pois o ministério não comprou mais.

Ou seja, mesmo que um livro não deixe de ser usado, de ser adotado por escolas e professores, a não aprovação do Ministério da Educação tem um impacto.

- Ah, claro, tem um grande impacto. Nesse caso que mencionei, a vendagem caiu violentamente. Inclusive porque o MEC comprava, por exemplo, de cada coleção, 30, 40 mil exemplares, e de repente o livro passou a vender 800 . Então, a coleção foi morrendo. Foi por isso que resolvi fazer outra coleção. Ela está pronta para ser editada por uma editora de Curitiba.

De alguma forma as observações feitas pelos avaliadores do MEC foram úteis para você? De alguma forma você as aproveitou, ou não?

- Algumas delas eram procedentes e outras não. Uma que não acho procedente, por exemplo, dizia que o livro não pode ter ideologia. Qualquer livro tem ideologia, por mais que a pessoa diga que tem isenção... 
Mas você não acha que é importante que haja uma política governamental de avaliação para compras de livros didáticos, principalmente pelo montante que essas compras envolvem?

- Acho perigoso.

Mas como é que o governo, então, compraria tantos livros?

- Pois é. Depende muito de como essa comissão é escolhida. Infelizmente, no Brasil, o bairrismo é muito grande. A gente, por exemplo, sabe que pernambucano não suporta baiano e vice-versa. Se vai para Santa Catarina, a rivalidade entre Blumenau e Joinville é imensa. Sem contar o problema econômico. Aí entra a influência das editoras de São Paulo. Inegavelmente, São Paulo é o centro econômico do Brasil e tem um peso enorme.

Qual é o papel das editoras nesse processo? Qual a sua experiência no que diz respeito à influência que elas exercem?

- Não há como provar, mas é claro que elas devem exercer um papel importante nisso. Nós vivemos numa sociedade capitalista, e o capital pesa muito em qualquer decisão. Se inegavelmente São Paulo tem as principais, ou as maiores editoras do Brasil, é claro que o poder dessas editoras é maior que o de outras. Tanto que muitas delas, agora, estão sen do compradas pelo capital internacional. São capitais espanhóis comprando editoras. Nessa sociedade capitalista em que nós vivemos, a concentração do capital é cada vez maior, e o peso disso acaba predominando sobre a qualidade do produto. Além disso, há a propaganda...

Ou seja, você acha que o poder econômico das editoras acaba produzindo distorções.

- Ah, claro que produz! Outra coisa perigosíssima é o uso da televisão como instrumento de educação. Os chamados telecursos. O diálogo entre professor e aluno em sala de aula é algo fundamental na educação. E é por isso que eu adoro dar aula; porque, embora biologicamente a gente vá acumulando idade, vá envelhecendo, a cabeça está sempre fresca. O contato com a juventude é uma verdadeira simbiose, e nos obriga a sermos pessoas atualizadas, para podermos cumprir a nossa função. Agora isso fica cada vez mais difícil porque, sobretudo a partir da ditadura, a profissão de professor foi chutada para o alto. Eu me lembro que, quando fiz o então chamado ginásio, o professor trabalhava num lugar só e não ia todo dia à escola. Não dava muitas aulas, morava numa casa, tinha mulher que não trabalhava, tinha filhos, enfim, tinha uma existência boa. Hoje, o professor, para poder viver, tem que trabalhar numa porção de lugares. Tem que ser o que eu chamo de camelô do ensino. E o ensino vem caindo violentamente. Quer dizer, culpar só a juventude não explica. É claro que a televisão está pesando nisso tudo, a internet está pesando... O capitalismo está 
cada vez mais desenvolvido no Brasil e está transformando essa massa de gente numa massa alienada, que só está pensando em tomar coca-cola e ver a TV Globo, em vez de estar estudando.

Aproveitando esse ponto que você está mencionando, gostaríamos de voltar à sua experiência como professor. Do alto de 40 anos como professor de ensino médio, mas também do segmento de quinta a oitava série, como você avalia a sua própria prática?

- A experiência foi maravilhosa. Claro que existe aluno que não deve gostar de mim. Mas quando eu encontro com alunos, de modo geral, eles têm sempre uma boa lembrança das minhas aulas. De uma maneira ou de outra, acho que contribuí para a formação de muita gente.

Tomando sua própria experiência, você diria que os alunos "pioraram" ao longo do tempo?

- É. A geração de hoje é uma geração diferente da de outras épocas. Como as gerações mudam! A gente muda, a sociedade muda. Hoje me parece que o interesse do aluno é outro. Ele tem uma grande preocupação com liberdade, mas não liberdade em termos políticos; é muito mais em termos individuais. Acho também que, inegavelmente, a ditadura teve um papel devastador na evolução da História no Brasil. A História vinha sofrendo um processo de renovação. A preocupação com o social, com o econômico, com o cultural vinha crescendo, em detrimento de uma História essencialmente política ou exclusivamente política. A tal ponto, por exemplo, que o general Antônio Carlos Murici, lá em Pernambuco, disse que o regime "ia acabar com essa História marxista". Como também foi dito pelo professor Aloísio Rossi, quando me substituiu na Gama Filho. Eu nunca fiz pregação marxista em sala de aula. Tenho uma visão marxista, mas isso não quer dizer que eu faça pregação marxista. Certo dia, fui fazer uma palestra em Campos, e um dos alunos me aprontou uma que, depois, ele me confessou ter feito de propósito. Fez uma pergunta, já sabendo qual deveria ser minha resposta: perguntou sobre a TFP, aquele movimento Tradição, Família e Propriedade. Eu não falei bem do movimento, e o cara que estava sentado na primeira fila era um dos dirigentes da TFP em Campos... Aí começou uma discussão terrível.

Você acha que, nos dias de hoje, os alunos continuam gostando de História ou não?

- Continuam interessados em História. Acho que gostam da minha aula. É porque eu brinco muito, conto muita coisa paralela. Âs vezes, eu canto. Por exemplo, falando sobre o governo de Vargas no Estado Novo, sobre o DIP, eu conto que um compositor fez uma música chamada $O$ bonde de São fanuário. E canto. "O original era assim: o bonde de São Fanuário leva mais um operário; só eu 
não vou trabalhar. Aí o DIP proibiu e ele mudou para: o bonde de São Fanuário leva mais um operário; sou eu que vou trabalhar. Só que o torcedor do Flamengo canta diferente: o bonde de São Fanuário leva mais um otário para ver o Vasco apanhar..." Canto músicas assim. Conto histórias, particularidades. Por exemplo, vou falar sobre a vinda da Corte em 1808, e conto coisas de D. João, da Carlota Joaquina. O aluno se motiva.

Ao longo da sua carreira, você chegou a enfrentar problemas com alunos e pais de alunos em relação a notas, ou a conteúdos?

- Eu me lembro de dois casos concretos. Se houve outros, ignorei. Eu dava aula na Universidade Gama Filho, e dei 0 para um aluno. No fim do ano, eu estava dizendo quem tinha que ficar em segunda época, e esse aluno disse: "Não. Eu não tenho 0. Pode olhar que a minha nota é 8." Olhei, e no lugar do meu 0 tinha um 8. Aí eu passei a dar nota por extenso, não mais por número. A secretaria havia alterado a nota, sem dúvida. O segundo caso foi justamente por causa do livro do Leo Huberman. Uma garota chegou para mim e contou: "Aquino, no ano passado você se livrou de uma boa." Perguntei o que tinha acontecido, e ela contou: "Eu estava com a fulana de tal estudando o livro do Huberman, o capítulo que você mandou ler, sobre revolução industrial, e aí chegou o pai dela, que é coronel do Exército, e disse: 'Mas que livro interessante. Deixa eu ver.' Aí o cara começou a ler o livro. 'Essa história é tão diferente de quando eu aprendi.' Até que chegou num capítulo que começa, mais ou menos, com o seguinte texto: 'Dezessete anos antes do fim do século XIX morreu Marx. Dezessete anos depois do início do século XX, Marx renasceu na revolução russa.' Aí ele concluiu: 'Esse livro é comunista. Vou lá na escola conversar'." Mas acho que não foi. E se foi, eu não sei.

E quanto à questão disciplinar?

- Eu dou soco na mesa e largo palavrão mesmo: "Isso aqui é sala de aula!" Fazendo palestra, se começar a fazer baderna, eu boto para fora do salão. Eu sou professor, vivo me atualizando, mas sou da velha guarda. Hoje, o aluno dorme em sala de aula, e o professor finge que não vê. Noutro dia, dei aula em um cursinho e tinha uma garota dormindo no fim da sala. Quando acabou a aula, bati no ombro dela e disse: "Na próxima aula, se você for dormir, eu te boto para fora." Ficou alertinha na aula seguinte. Eu brinco com os alunos, mas na hora de trabalhar... Se você pegar ex-aluno meu, eles vão dizer isso que estou contando, que eu brincava em sala de aula, que eles me consideravam amigo deles, tinham confiança em mim, mas que hora de trabalhar era de trabalhar, e hora de brincar era de brincar. 
Hoje em dia, por razões óbvias, você dá um número bem menor de aulas e dedica parte do seu tempo a participar de debates, palestras. Conte um pouco sobre essas atividades.

- Na semana passada, fui convidado, junto com o Antônio Modesto e outras pessoas, a ir ao Pedro II do Humaitá para discutir a ditadura. A proposta era passar um filme e depois abrir a discussão. A gente falava, depois os alunos perguntavam. Isso foi na terça-feira de manhã, de 15 para as oito até as dez e pouco. Excepcional o comportamento deles. De tarde, a mesma coisa, foi de 25 para as duas até as cinco e meia. $\mathrm{E}$ depois, foi na quinta-feira de noite, de 15 para as sete até nove e meia, mais ou menos, dez horas. A repercussão foi tão grande que sábado a gente vai fazer a mesma coisa no Pedro II da Tijuca. Interesse deles. A sala cheia. E você não vê ninguém conversando.

Queríamos agradecer por você nos ter concedido seu tempo para essa conversa. As palavras finais são suas.

- Para mim foi uma satisfação e fico com o ego massageado sabendo que a entrevista será publicada. A gente, como professor, e principalmente como professor de História, tem consciência de que trabalha com a vida, trabalha com a formação do cidadão. Daí a nossa importância na construção de uma sociedade soberana, justa, humana, solidária - a minha também é socialista. É um sonho. Apesar de eu estar com 79 anos, continuo atuando. Estou na chapa de oposição do sindicato, fui do Comitê Brasileiro da Anistia, fui vice-presidente do Tortura Nunca Mais, ${ }^{12}$ continuo sendo Flamengo, sendo Mangueira e, hoje, amando a Lúcia.

1. Na época, o chamado ensino primário tinha cinco anos. A seguir vinha o ensino secundário, composto pelo curso ginasial, de quatro anos, e pelo colegial, de três, oferecido em duas modalidades: curso científico, com maior concentração na área de ciências exatas e biológicas, e curso clássico, com ênfase na área de humanidades. Os que desejavam obter o diploma de professor primário, em vez do curso colegial, faziam o curso normal.

2. Pedro Mota Lima (1898-1966), jornalista, foi fundador de vários jornais vinculados ao PCB e autor dos romances Coronel Lousada (1925), Bruhaha (1935), Zamor (1940) e Idade da pedra (1950). 
3. Órgão oficioso do PCB, o jornal circulou até 1958 . Voltou a ser editado no site do PCB.

4. O professor Eremildo Viana foi, reconhecidamente, um dos que colaboraram com o regime militar, indicando colegas que teriam participação política dentro da Faculdade Nacional de Filosofia.

5. Anísio Teixeira (1900-1977), educador, foi o principal difusor do movimento da Escola Nova e teve papel-chave no processo de modernização da educação brasileira entre as décadas de $1930 \mathrm{e}$ 1960.

6. Refere-se à Campanha da Legalidade, liderada por Leonel Brizola, então governador do Rio Grande do Sul, para garantir a posse do vice-presidente João Goulart diante da renúncia do presidente Jânio Quadros em agosto de 1961.

7. O governo do general Emílio Médici (30 de outubro de 1969 a 15 de março de 1974) é considerado o mais repressivo do regime militar.

8. O Movimento Revolucionário 8 de Outubro rememorava a data da morte de Ernesto "Che" Guevara.
9. Partido Socialista dos Trabalhadores Unificados, agremiação de esquerda fundada por diferentes organizações, grupos e ativistas independentes, que se apresenta como uma nova alternativa revolucionária implantada em setores fundamentais dos movimentos sindical e estudantil.

10. Ciclo de três anos, posterior ao ensino fundamental, que tem hoje oito anos.

11. A Editora Brasiliense possuía nos anos 1970 uma coleção chamada Tudo é História. Os livros foram inovadores pelo tamanho, facilidade e objetividade da leitura, além de preços acessíveis.

12. O Comitê Brasileiro pela Anistia, criado em 1968, congregou os esforços de diversas entidades e personalidades na luta pela anistia e contra as perseguições políticas, prisões e torturas levadas a efeito pelo regime militar. Criado em 1985, o grupo Tortura Nunca Mais é formado por ex-presos políticos e familiares de desaparecidos políticos e tem como objetivo defender os direitos humanos e lutar pelo esclarecimento das mortes e desaparecimentos de militantes que lutaram contra o regime militar. 